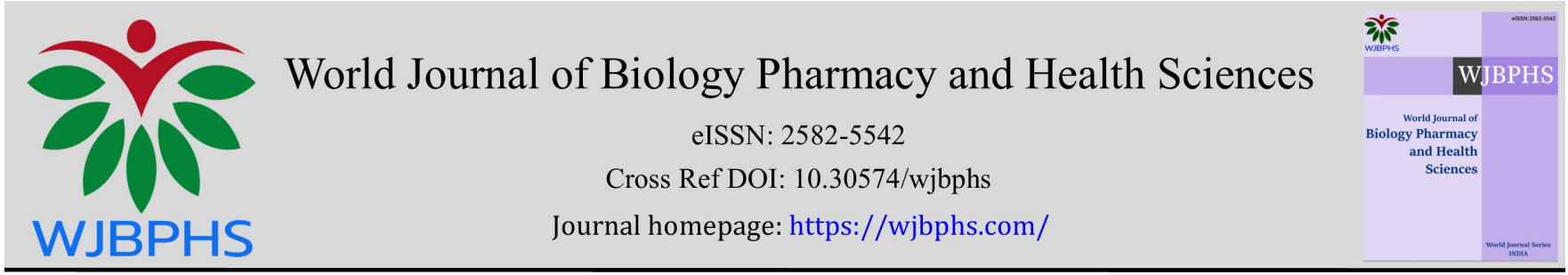

(RESEARCH ARTiCLE)

\title{
Utilization of Euphorbia hirta L. for traditional medicine and its bioactivity
}

\author{
Marina Silalahi * \\ Prodi Pendidikan Biologi, Fakultas Keguruan dan Ilmu Pendidikan, Universitas Kristen Indonesia. Jl. Mayjen Sutoyo No. 2 \\ Cawang, Jakarta Timur.
}

World Journal of Biology Pharmacy and Health Sciences, 2021, 08(01), 053-058

Publication history: Received on 04 September 2021; revised on 16 October 2021; accepted on 18 October 2021

Article DOI: https://doi.org/10.30574/wjbphs.2021.8.1.0109

\begin{abstract}
Euphorbia hirta is a species belonging Euphorbiaceae has been long used by humans as traditional medicine. The plants used as traditional medicine is related to secondary metabolites and its bioactivity. This study aims to explain the utilization and bioactivity of $E$. hirta. The methods to writing articles is based on a review of articles or research results published online, especially on google scholar, using the keywords Euphorbia hirta, uses of E. hirta and bioactivity of E. hirta then synthesized so that explain the benefits and its bioactivity. Euphorbia hirta is a weed, so that is easily found in the environment which is characterized by the presence of white sap and has cyathia inflorescence. In the traditional medicine E. hirta is used to treat ulcers, dysentery, gastrointestinal infections, skin infections, diabetes mellitus and respiratory disorders are diseases caused by microbial infections. Bioactivity of $E$. hirta is antimicrobial, antioxidant, anti-diabetes mellitus, anti-stress, anti-cancer and anti-kidney stones. The $E$. hirta extract contains dedquercetrin, dimethoxyquercetrin, hirta coumaroflavonoside, and hirta flavonoside- $B$ which bioctivity to inhibit $\alpha$-glucosidase activity comparable to acarbose so that it is potential to be developed as anti-diabetes mellitus.
\end{abstract}

Keywords: Euphorbia hirta; Anti-microbial; Anti diabetes-mellitus; Traditional medicine

\section{Introduction}

Euphorbia hirta, by the Indonesia local people I known as patikan kebo, is a medicinal plant that has been long used as traditional medicine. This plant is easy to find in the surrounding environment such as yards, roadsides, gardens, rice fields and other land. The patikan kebo is easily recognized by the white sap it produces $[1,2]$.

In traditional medicine, $E$. hirta leaves are used to treatment of ulcers, overcoming dysentery, digestive tract infections, and skin infections $[3,4]$ which are mostly caused by microbial infections. In addition, Rahyana et al [5] reported that $E$. hirta is also used for the treatment of diabetes, respiratory disorders and gastro-intestinal disorders. Abubakar [6] stated that microbes such as Escherichia coli, Klebsiella pneumoniae, Shigella dysentriae, Salmonella typhi and Proteus mirabilis are a group of gram-negative bacteria that often cause gastrointestinal infections in humans. Various researchers have successfully reported the bioactivity of E. hirta as antimicrobial, antioxidant, anti-diabetic, and antistress.

The use of plants as traditional medicine is related to the content of their secondary metabolites. Secondary metabolites are compounds produced from secondary metabolic processes using various intermediates produced from primary metabolic processes [7]. The results of phytochemical screening showed that E. hirta contains tannins, flavonoids, alkaloids, glycosides, and saponins [4,8]. Upadhyay et al [8] stated that terpenes, tannins, alkaloids and flavonoids of $E$. hirta to be responsible for its antimicrobial properties.

\footnotetext{
*Corresponding author: Marina Silalahi; E-mail:marina.silalahi@uki.ac.id

Prodi Pendidikan Biologi, Fakultas Keguruan dan Ilmu Pendidikan, Universitas Kristen Indonesia. Jl. Mayjen Sutoyo No. 2 Cawang, Jakarta Timur.
}

Copyright (C) 2021 Author(s) retain the copyright of this article. This article is published under the terms of the Creative Commons Attribution Liscense 4.0. 
The use of natural ingredients as traditional medicines such as E. hirta is considered safer than synthetic drugs, because natural ingredients are easily degraded in the human body. However, the assumption that traditional medicinal ingredients do not have side effects is not entirely correct, therefore the dosage and processing are appropriate so that side effects and toxicity can be minimized. For example, the use of young leaves (raw leaf juice) of Sauropus androgynus as a slimming drug has been reported to cause lung disorders known as bronchiolitis obliterans [9]. Long-term oral administration of $E$. hirta extract for 90 days does not cause sub-chronic toxicity [10].

Until now, the review of the benefits and bioactivity of $E$. hirta is still very limited. This study aims to reveal the relationship between the use of E. hirta as a traditional medicine and its bioactivity so that its development prospects can be improved.

\section{Methods}

This research is a literature review to reveal the benefits and bioactivity of $E$. hirta. Literature sources come from online, especially from Google scholar using the keywords E. hirta, bioactivity of E. hirta, and uses E. hirta. The literature obtained is synthesized so that the benefits and bioactivity of E. hirta can be explained comprehensively.

\section{Results and discussion}

\subsection{Botany of Euphorbia hirta L.}

Euphorbia hirta is one of the species in the Euphorbiaceae family which is widely used as traditional medicine. The genus Euphorbia is easily distinguished by its milky latex and specialized inflorescence (cyathia) [1,2]. Description is a chronic herb with branching that bends with a height of up to $60 \mathrm{~cm}$. Stems are reddish or purple in color, with abundant latex and hairy (Fig. 1A). The leaves are simple leaves that are located opposite long internodes with stipules. Leaf blade lanceolate-oval, at the base different or not the same; one side is cuneate, the other side is beveled round (Fig. 1B). The apex of the acute leaf is 3-4 cm long and 1-1.4 cm wide. The edges of the leaves are finely toothed, sometimes with purple spots near the midrib, sometimes purple with spots near the midrib. Inflorescence and monoecious flowers that appear to form clusters in the terminal or axillary part called cyathium and some cyathia are arranged in cyme (Fig. 1C). Male and female flowers are condensed in one involucre and both are apetala. Male flowers are sessile, bracteole is linear, perianth is absent, and has 1 stamen. The female flower has a small pedicel, the ovary is higher, covered with small hairs. Usually flowers all year round. Allomorphic fruit has 3 lobes covered with short hairs. Seeds oval, prismatic 4 sides, wrinkled and pinkish-brown in color, seed 3 capsules [11].

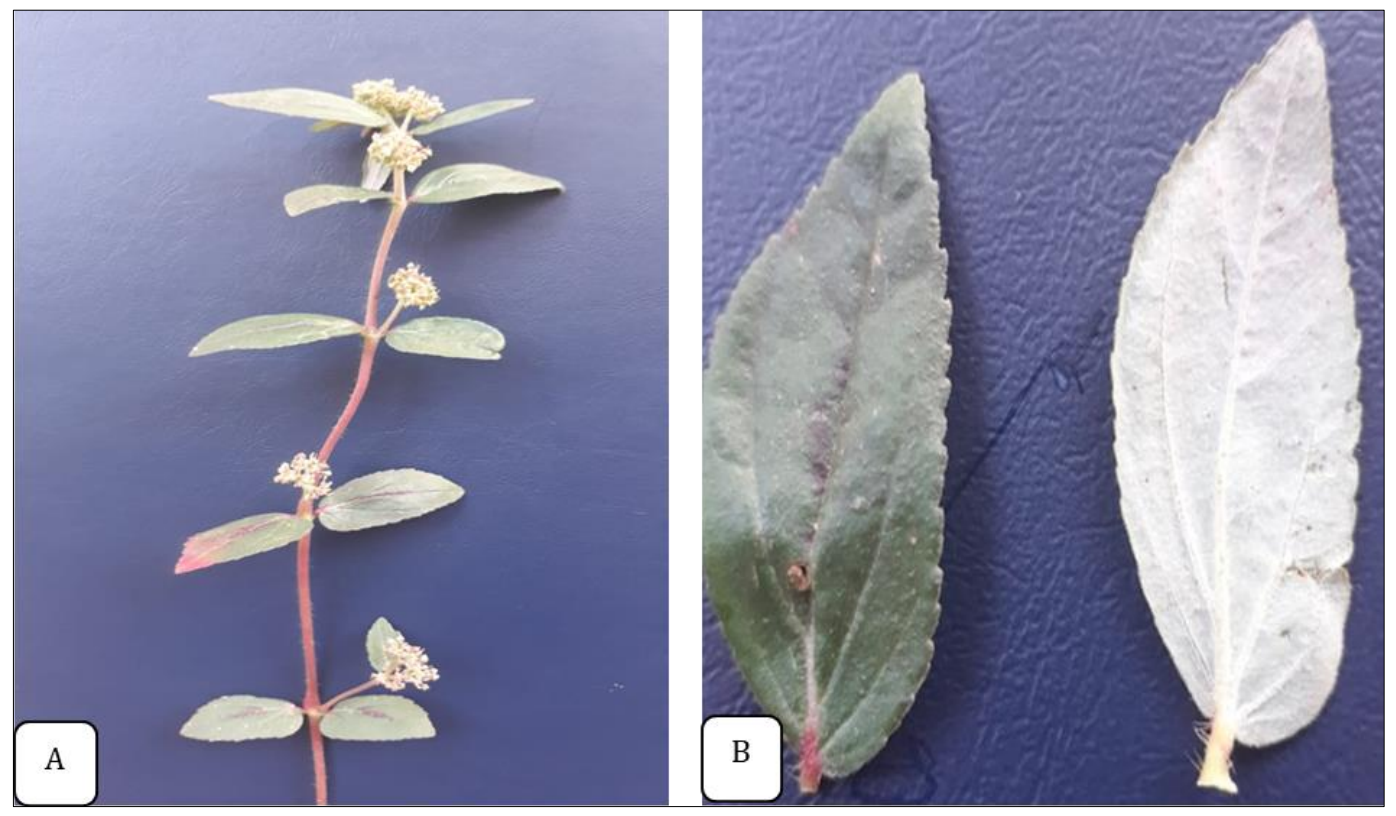

Figure 1 Euphorbia hirta. A. Stem has internodes, leaves and inflorescence. B. Leaf 


\subsection{Bioaktivitas Euphorbia hirta L.}

\subsubsection{Anti-microbial}

Antimicrobial compounds are compounds that inhibit the growth or cause death of microbes. Various pathogenic microbes cause various diseases in humans, therefore plants that produce antimicrobial compounds have the potential to be developed for infectious drugs, especially digestive tract infections. Euphorbia hirta leaves are traditionally used for the treatment of ulcers, overcoming dysentery, digestive tract infections and skin infections $[3,4]$. Escherichia coli, Klebsiella pneumoniae, Shigella dysentriae, Salmonella typhi and Proteus mirabilis are a group of gram-negative bacteria that often cause gastrointestinal infections in humans [6].

Utilization of E. hirta as an antimicrobial against yeast [12] and bacteria [13]. Ethanol, methanol, chloroform and aqueous extracts of leaves, stems, roots and all parts of E. hirta have antibacterial activity [8] and fungi (Aspergillus niger, Aspergillus fumigate, Arthrographis cuboidea) by agar disk diffusion method [14]. E. hirta leaf extract inhibited the growth of Candida albicans with a minimum inhibitory concentration (MIC) of $25 \mathrm{mg} / \mathrm{ml}$ but the concentration was still higher than the standard compound nystatin (MIC $0.165 \mathrm{mg} / \mathrm{ml}$ ). Nystatin is a commercial drug to treat fungal infections, especially Candida [12]. EH extract causes damage to fungal cell membranes resulting in leakage of cellular proteins [15]. Phytochemical screening of E. hirta contains alkaloids, flavonoids, saponins, terpenoids, steroids and sterols. Methanol, chloroform, and hexane extracts of E. hirta leaves and fruit inhibited the growth of Proteus mirabilis, Listeria monocytogenes, Clostridium absonum, Aspergillus niger, Aspergillus fumigate, Arthrographis cuboidea by agar disk diffusion method [14].

The bioactivity of E. hirta as an anti-bacterial is more dominantly reported than others. The $E$. hirta extract inhibits the growth of bacteria such as Staphylococcus aureus [8,13,16,17], Salmonella typhi [16,18], Escherichia coli, Klebsiella pneumoniae, Bacillus subtilis [8,17], Proteus vulgaris [8,16], Pseudomonas aeruginosa [16,17], Klebsiella pneumoniae [8], Haemophilus influenzae, Pseudomonas aeruginosa, Shigella [16], Proteus mirabilis, Listeria monocytogenes, and Clostridium absonum [14]. The ability of E. hirta extract as an antimicrobial is influenced by many factors including the substance used for extraction [18] and concentration. The E. hirta extract inhibited the growth of Staphylococcus aureus (MIC $25 \mathrm{mg} / \mathrm{ml}$ ) higher than the standard drug erythromycin (MIC $0.005 \mathrm{mg} / \mathrm{ml}$ ) [13]. The antibacterial activity of $E$. hirta ethanol extract is higher than that of methanol, water and chloroform [8].

\subsubsection{Antioxidants}

Antioxidant compounds are compounds that protect cells from free radical damage. Various degenerative diseases such as cancer and heart disease are often associated with free radicals, therefore, anti-oxidants indirectly have implications for these diseases. In laboratory experiments its bioactivity as an antioxidant can be tested using the DPPH (1,1Diphenyl-2-picryl Hydrazil) immersion method. The bioactivity of $E$. hirta as an antioxidant has been widely reported. The whole of $E$. hirta organs had scavenging activity but varied, namely leaf extract (72.96 $\pm 0.78 \%$ ) while flower extract $(52.45 \pm 0.66 \%)$, roots $(48.59 \pm 0.97 \%)$ and stems. of and $(44.42 \pm 0.94)$ [19]. When compared with the standard compound butylated hydroxytoluene (BHT) antioxidant, it is not much different (75.13 $\pm 0.75 \%)$. Antioxidant bioactivity is closely related to phenolic content, therefore the content of phenolic compounds is directly proportional to the antioxidant [18]. Leaf extract contains the highest phenolic compounds at $206.17 \pm 1.95 \mathrm{mg}$ GAE/g followed by flowers, roots and stems at 117.08 $\pm 3.01 ; 83.15 \pm 1.19$; and $65.70 \pm 1.72 \mathrm{mg} \mathrm{GAE} / \mathrm{g}$ [19]. Asha et al [20] reported that inhibition with IC50 values of free radicals was lower than aqueous and methanol extracts. The E. hirta ethanol extract (0.5 $\mathrm{mg} / \mathrm{mL})$ showed DPPH scavenging activity of $61.19 \% \pm 0.22 \%$, while the positive control $(0.5 \mathrm{mg} / \mathrm{mL}$ of ascorbic acid $)$ had $100 \% \pm 0.22 \%$ activity [21]. Extracts of leaves, stems, flowers and roots of $E$. hirta contain phenolic and flavonoids which have antioxidant activity in vitro by diphenyl-1-picrylhydrazyl (DPPH) assay and reducing power was measured using the cyanoferrate method [18].

\subsubsection{Anti-diabetes mellitus}

Anti-diabetes mellitus compounds are compounds that are able to inhibit the breakdown of sugar in the blood or inhibit $\alpha$-glucosidase [5]. In laboratory experiments, diabetes rats can be induced by administration of streptozotocin. Glibenclamide [22] and acarbose [5] are standard drugs used as anti-diabetics. Oral administration of E. hirta extract at a dose of E. hirta (400 mg/kg b. wt) in a group of diabetic rats reduced blood sugar levels in streptozotocin-induced diabetic rats. Reduction in blood sugar can be seen from the $7^{\text {th }}$ day after continuous administration of the extract. The effect of $E$. hirta extract on diabetic rats also showed a significant decrease in total cholesterol, low density lipoprotein (LDL) cholesterol, and very low density lipoprotein (VLDL) cholesterol increase in high density lipoprotein (HDL) cholesterol in diabetic rats. This shows that E. hirta has significant hypoglycemic and antihyperlipidemic effects [5]. 
The ethyl acetate fraction of the whole E. hirta contains dedquercetrin, dimethoxyquercet-rin, together with two flavonoids known as hirta coumaroflavonoside, and hirta flavonoside-B exhibited dose-dependent and comparable inhibition of -glucosidase. Maximum $\alpha$-glucosidase inhibition was achieved with hirta coumaroflavonoside (IC50 0.022 $\mathrm{mM}$ ) followed by hirta flavonoside-B (IC50 $0.071 \mathrm{mM}$ ) compared to acarbose (IC50 $0.092 \mathrm{mM}$ ). The compound hirta coumaroflavonoside showed non-competitive inhibition while the compound dedquercetrin, dimethoxyquercetrin and hirta flavonoside-B showed a mixed non-competitive inhibition pattern [5].

\subsubsection{Anti-cancer}

Anti-cancer compounds are compounds that can inhibit cell growth. Various cancer cells that cause many human deaths such as lung cancer, liver cancer and breast cancer. The E. hirta has cytotoxic activity, cell cycle arrest, and induces apoptosis in MCF-7 breast cancer cells [23]. The E. hirta methanol extract containing flavanol glycosides afzelin, quercitrin, and myricitrin showed slight cytotoxicity against human epidermoid carcinoma cells KB 3-1 [24].

The cytotoxic activity of the methanol extract of all E. hirta sections was determined by the MTT assay at various concentrations ranging from 1.96 to $250.00 \mathrm{mg} / \mathrm{mL}$ in MCF-7 cells. The $E$. hirta extract showed significant inhibition of MCF-7 cell survival and the value (IC50) was $25.26 \mathrm{mg} / \mathrm{mL}$ at 24 hours. Microscopic studies showed that E. hirta treated cells exhibited morphological features characterized by apoptosis. Flow cytometry studies confirmed that E. hirta extract induced apoptosis in MCF-7 cells. The E. hirta causes DNA fragmentation in MCF-7 cells which results in cell accumulation in the $\mathrm{S}$ and G2/M phases of apoptosis [23].

\subsubsection{Anti-stress}

Chronic stress is known to cause impaired learning and memory and triggers several affective disorders including depression and anxiety. Drugs of natural origin are known to have several central nervous system effects and are emerging as promising alternative therapies [25]. The hydroalcoholic extract of $E$. hirta had anxiolytic activity in rats subjected to chronic stress to high plus labyrinth (EPM) and open field assay (OFT). Administration of E. hirta (200 mg $=\mathrm{kg}$, p.o for seven days) exhibited anti-anxiety activity characterized by chronic stress immobilization. In contrast, stress-induced swimming stress-induced anxiety was only partially reduced by $E$. hirta. Co-treatment of rats with flumazenil $(0.5 \mathrm{mg}=\mathrm{kg}$, i.p.), bicuculline $(1 \mathrm{mg}=\mathrm{kg}$, i.p.) or picrotoxin ( $1 \mathrm{mg}=\mathrm{kg}$, i.p.) resulted in a significant reduction in the anxiolytic effect of $E$. hirta indicating that its action is mediated via the GABA-receptor. benzodiazepine receptors [25].

Depression is a mood disorder characterized by deep feelings of sadness. Giving antidepressant drugs can increase the levels of serotonin or feel-good compounds in the brain. Anuradha et al. [26] reported that E. hirta bioactivity has anxiolytic and antidepressant effects. Anxiolytics are compounds in medications that help treat symptoms of anxiety, such as generalized anxiety disorder. Experimental results in rats subjected to chronic immobilization stress (CIS) but not in rats subjected to forced swimming stress (FSS). Effects of E. hirta treatment in mice exposed to CIS or FSS on acetylcholinesterase (AChE) activity in the frontal cortex, hippocampus, and septum. Chronic immobilization stress (CIS) increased acetylcholinesterase (AChE) activity in all three regions, while E. hirta treatment returned it to normal levels. Forced swimming stress (FSS) increased AChE activity only in the septum, and E. hirta administration slightly restored this to normal levels [26].

\subsubsection{Anti-kidney stone}

Kidneys are organs of the human body that function to filter blood. Kidney stone disease or nephrolithiasis is the formation of hard, stone-like material derived from minerals and salts in the kidneys. Diuretics are drugs used to remove excess salt and water from the body through urine. The diuretic effect of $E$. hirta leaf extract was assessed in rats using acetazolamide and furosemide as standard diuretic drugs. The E. hirta aqueous and ethanol extracts (50 and $100 \mathrm{mg}$ : $\mathrm{kg}$ ) resulted in increased urine output. The aqueous extract of $E$. hirta increased urinary $\mathrm{Na}, \mathrm{K}_{\text {and }} \mathrm{HCO}_{3}$ excretion and conversely the ethanolic extract increased $\mathrm{HCO}_{3}$ excretion, decreased $\mathrm{K}$ loss and had little effect on renal Na removal. Acetazolamide, like the aqueous extract of E. hirta, increases urine output and increases the excretion of $\mathrm{Na}_{1} \mathrm{~K}_{\text {and }} \mathrm{HCO}_{3}$. The active component(s) in the aqueous extract of $E$. hirta leaves has a diuretic spectrum similar to acetazolamide, so it can be used as a diuretic agent [27].

\subsection{Toxicity}

The assumption that traditional medicinal ingredients do not have side effects is not entirely true, therefore proper dosage adjustment is very important to avoid their toxicity. Long-term oral administration of E. hirta extract for 90 days 
did not cause sub-chronic toxicity [10]. Toxicity test is a scientifically developed method to determine the correct concentration of medicinal plants. Administration of E. hirta extract in Sprague Dawley rats at a single dose of 5000 $\mathrm{mg} / \mathrm{kg}$ for 14 days did not produce any signs of toxicity. The LD50 E. hirta is estimated to be over $5000 \mathrm{mg} / \mathrm{kg}$. In repeated dose 90 -day oral toxicity studies, administration of $50 \mathrm{mg} / \mathrm{kg}, 250 \mathrm{mg} / \mathrm{kg}$, and $1000 \mathrm{mg} / \mathrm{kg} / \mathrm{day}$ of E. hirta extract per body weight did not show significant differences ( 000.05 ) in food and water consumption, changes in body weight, hematological and biochemical parameters, relative organ weights compared to the control group. Macro pathological and histopathological examination of all organs including the liver did not show any morphological changes [13].

The E. hirta ethanol extract fraction and given to rats in graded doses of $400 \mathrm{mg} / \mathrm{kg}, 800 \mathrm{mg} / \mathrm{kg}$ and $1600 \mathrm{mg} / \mathrm{kg}$ for 14 days caused a significant increase in total levels of protein, albumin, globulin, alanine aminotransferase (ALT), alkaline phosphatase (ALP). ), aspartate amino transferase (AST), total bilirubin, creatinine, and blood urea nitrogen (BUN). Some fractions also cause a significant decrease in the level of conjugated bilirubin. Some chromatographic fractions of E. hirta have the potential to have deleterious effects on rat serum chemistry and therefore caution should be exercised in the use of E. hirta as a medicinal plant [28].

\section{Conclusion}

In traditional medicine $E$. hirta is used to treat ulcers, dysentery, gastrointestinal infections, skin infections, diabetes mellitus and respiratory disorders, especially diseases caused by microbial infections. The bioactivity of E. hirta is antimicrobial, antioxidant, anti-diabetic, anti-stress, anti-cancer and anti-kidney stones. The E. hirta extract contains dedquercetrin, dimethoxyquercetrin, hirta coumaroflavonoside, and hirta flavonoside-B which function to inhibit $\alpha$ glucosidase activity comparable to acarbose so it is very potential to be developed as an anti-diabetes mellitus.

\section{Compliance with ethical standards}

\section{Acknowledgments}

I express my gratitude to the Indonesian Christian university for funding this research.

\section{References}

[1] Govaerts R, Frodin DG, Radcliffe-Smith A. World checklist and bibliography of Euphorbiaceae (with Pandaceae). Kew, Royal Botanic Gardens. 2000; 2.

[2] Horn JW, Van Ee BW, Morawetz JJ, Riina R, Steinmann VW, Berry PE, Wurdack KJ. Phylogenetics and the evolution of major structural characters in the giant genus Euphorbia L. (Euphorbiaceae). Mol. Phylogenet. Evol. 2012; 63: 305-326.

[3] Ogbulie JN, Ogueke CC, Okoli IC, Anyanwu BN. Antibacterial activities and toxicological potentials of crude ethanolic extracts of Euphorbia hirta. African Journal of Biotechnology 6(13): 1544-1548.

[4] Upadhyay B, Singh KP, Kumar A. Pharmacognostical and antibacterial studies of different extracts of Euphorbia hirta L. Journal of Phytology. 2010; 2(6): 55-60.

[5] Rayhana MAB, Ali A, Pillai KK, Aeri V, Sharma M, Mir SR. Inhibition of $\alpha$-glucosidase by newprenylated flavonoids from Euphorbia hirta L. Journal of Ethnopharmacology. 2015; 176: 1-8.

[6] Abubakar EMM. Antibacterial activity of crude extracts of Euphorbia hirta against some bacteria associated with enteric infections. Journal of Medicinal Plants Research. 2009; 3(7): 498-505.

[7] Taiz L, Zeiger E. Plant Physiology. 5th Edition, Sinauer Associates Inc., Sunderland. 2010; 782.

[8] Kumar OA, Naidu LM, Raja Rao KG. Antibacterial evaluation of snake weed (Euphorbia hirta L.). Journal of Phytology. 2010; 2(3): 08-12.

[9] Bunawan H, Bunawan SN, Noor NM. Sauropus androgynus (L.) Merr. induced bronchiolitis obliterans: from botanical studies to toxicology. Evidence Based Complementary and Alternative Medicine. 2015; Article ID 714158: 1-7. 
[10] Ping KY, Darah I, Chen Y, Sreeramanan S, Sasidharan S. Acute and sub chronic toxicity study of Euphorbia hirta L. methanol extract in rats. Hindawi Publishing Corporation BioMed Research International. 2013; Article ID 182064: 14.

[11] Ghosh P, Ghosh C, Das S, Das C, Mandal S, Chatterjee S. Botanical description, phytochemical constituents and pharmacological properties of Euphorbia hirta. Linn: a review. International Journal of Health Sciences \& Research. 2019; 9(3): 273-286.

[12] Jackson C, Agboke A, Nwoke V. In vitro evaluation of antimicrobial activity of combinations of nystatin and Euphorbia hirta leaf extract against Candida albicans by the checkerboard method. Journal of Medicinal Plants Research. 2009; 3(9): 666-669.

[13] Adikwu M, Jackson C, Esimone C. Evaluation of in vitro antimicrobial effect of combinations of erythromycin and Euphorbia hirta leaf extract against Staphylococcus aureus. Research In Pharmaceutical Biotechnology. 2010; 2(2): 22-24.

[14] Ahmad W, Singh S, Kumar S. Phytochemical screening and antimicrobial study of Euphorbia hirta extracts. Journal of Medicinal Plants Studies. 2017; 5(2): 183-186.

[15] Gayathri A, Ramesh KV. Antifungal activity of Euphorbia hirta L. inflorescence extract against Aspergillus flavus A mode of action study. Int. J. Curr. Microbiol. App. Sci. 2013; 2(4): 31-37.

[16] Titilope KK, Rashidat EA, Christiana OC, Kehinde ER, Omobolaji JN, Olajide, AJ. In-vitro antimicrobial activities of Euphorbia hirta against some clinical isolates. Agric. Biol. J. N. Am. 2012; 3(4): 169-174.

[17] Suresh K. Antimicrobial and phytochemical investigation of the leaves of Carica papaya L., Cynodon dactylon (L.) Pers., Euphorbia hirta L., Melia azedarach L. and Psidium guajava L. Ethnobotanical Leaflets. 2008 ; (1): 157.

[18] Perumal S, Mahmud R, Pillai S, Lee WC, Ramanathan S. Antimicrobial activity and cytotoxicity evaluation of Euphorbia hirta (L.) extracts from Malaysia. APCBEE Procedia. 2012; 2: 80-85.

[19] Basma AA, Zakaria Z, Latha LY, Sasidhraan S. Antioxidant activity and phytochemical screening of the methanol extract of Euphorbia hirta L. Asian Pacific Journal of Tropical Medicine. 2011; 386-390.

[20] Asha S, Thirunavukkarasu P, Mani VM, Sadiq AM. Antioxidant activity of Euphorbia hirta Linn leaves extracts. European Journal of Medicinal Plants. 2016; 14(1): 1-14.

[21] Sharma N, Samarakoon KW, Gyawali R, Park YH, Lee SJ, Oh SJ, Jeong DK. Evaluation of the antioxidant, antiinflammatory, and anticancer activities of Euphorbia hirta ethanolic extract. Molecules. 2014; 19(9): 1456714581.

[22] Maurya AK, Tripathi S, Ahmed Z, Sahu RK. Antidiabetic and antihyperlipidemic effect of Euphorbia hirta in streptozotocin induced diabetic rats. Der Pharmacia Lettre. 2012; 4(2): 703-707.

[23] Kwan YP, Saito T, Ibrahim B, Al-Hassan FMS, Oon CE, Chen Y, Jothy SL, Kanwar JR, Sasidharan S. Evaluation of the cytotoxicity, cell-cycle arrest, and apoptotic induction by Euphorbia hirta in MCF-7. breast cancer cells Pharm Biol. 2016; 54(7): 122-1236.

[24] Liu Y, Murakami N, Ji H, Abreu P, Zhang S. Antimalarial flavanol glycosides from Euphorbia hirta. Pharmaceutical Biology. 2007; 45(4): 278-281.

[25] Anuradha H, Srikumar BN, S Rao BSS, Lakshmana M. Euphorbia hirta reverses chronic stress-induced anxiety and mediates its action through the GABAA receptor benzodiazepine receptor-Cl2 channel complex. J Neural Transm. 2008; 115: 35-42.

[26] Anuradha H, Srikumar BN, Deepti N, Rao BSS, Lakshmana M. Restoration of acetylcholinesterase activity by Euphorbia hirta in discrete brain regions of chronically stressed rats. Pharmaceutical Biology. 2010; 48(5): 499503.

[27] Johnson PB, Abdurahman EM, Tiam EA, Abdu-Aguye I, Hussaini IM. Euphorbia hirta leaf extracts increase urine output and electrolytes in rats. Journal of Ethnopharmacology. 1999; 65: 63-69.

[28] Adedapo AA, Abatan MO, Idowu SO, Olorunsogo 00. Effects of chromatographic fractions of Euphorbia hirta on the rat serum biochemistry. African Journal of Biomedical Research. 2005; 8: 185-189. 